\title{
Early Placenta Insulin-Like Peptide
}

National Cancer Institute

\section{Source}

National Cancer Institute. Early Placenta Insulin-Like Peptide. NCI Thesaurus. Code C39673.

Early placenta insulin-like peptide (139 aa, $15 \mathrm{kDa}$ ) is encoded by the human INSL4 gene.

This protein plays a role in both trophoblast development and bone formation. 